\title{
E-Learning as a teaching alternative for graduate students in Information Technology Management and Administration at the National University of Trujillo [Aprendizaje Electrónico como alternativa de enseñanza para los alumnos de posgrado en Administración y Dirección de las Tecnologías de Información de la Universidad Nacional de Trujillo]
}

\author{
José A. Gómeza, ${ }^{a}$, Franklin A. Díaz ${ }^{b}$, Juan A. Vegaa ${ }^{a}$ Elka J. Chávezc \\ a Facultad de Ingeniería, Universidad Nacional de Trujillo. Av. Juan Pablo II s/n - Ciudad \\ Universitaria, Trujillo, Perú

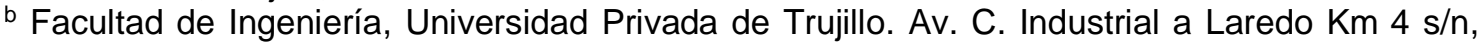 \\ Trujillo, Perú \\ c Facultad de Educación y Ciencias de la Comunicación, Universidad Nacional de Trujillo. Av. \\ Juan Pablo II s/n - Ciudad Universitaria, Trujillo, Perú
}

*jgomez@unitru.edu.pe

Received: 20 November 2020; Accepted: 24 November 2020; Published: 29 November 2020

\section{Resumen}

Este trabajo de investigación se ha desarrollado con el propósito de evaluar y considerar una alternativa de aprendizaje haciendo uso de las tecnologías de la información y la comunicación, y poder aplicarlas en el servicio educativo que brinda la Escuela de Posgrado de la Universidad Nacional de Trujillo a estudiantes con especialización en Administración y Gestión de Tecnologías de la Información. Los indicadores utilizados fueron: modelo pedagógico, curso y herramienta virtual, para evaluar el grado de participación. Se contrastó la hipótesis aplicando el diseño pre-experimental con pre-test y post-test. El resultado obtenido de los coeficientes significativos de los indicadores de la preprueba fue $0,65,0,325,0,725,0,55,0,475,0,676$ y la postprueba fue $0,05,0,1,0,1,0,1 ; 0,075,0,025$ respectivamente. Se determinó que no existe contradicción dentro de cada uno de los indicadores, pues los resultados muestran que en cada indicador luego de utilizar el sistema E-Learning, se obtuvo una mayor participación de los estudiantes en el desarrollo de las actividades académicas.

Palabras clave: Servicio educativo, aprendizaje no presencial, Sistema de e-learning.

\begin{abstract}
This research work has been developed with the purpose of evaluating and considering a learning alternative making use of information and communication technologies, and being able to apply them in the educational service provided by the Graduate School of the Universidad Nacional de Trujillo to students with a specialization in Administration and Management of Information Technology. The indicators used were: pedagogical model, course and virtual tool, to evaluate the degree of participation. The hypothesis was tested by applying the pre-experimental design with pre-test and post-test. The result obtained from the significant coefficients of the pre-test indicators was $0.65,0.325,0.725,0.55,0.475,0.676$ and the post-test was $0.05,0.1,0.1,0.1$; $0.075,0.025$ respectively. It was determined that there is no contradiction within each of the indicators, since the results show that in each indicator after using the E-Learning system, a greater participation of students was obtained in the development of academic activities.
\end{abstract}

Keywords: Educational service, non-face learning, e-learning system. 


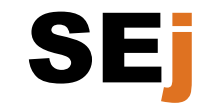

Vol. 4, $\mathrm{N}^{\circ} 2,2020$

\section{Journal of Sciences and Engineering}

Copyright (C) 2020, CINCADER.

ISSN 2523-9503

DOI: https://doi.org/10.32829/sej.v4i2.183

\section{Introduction}

The Graduate School of the Universidad Nacional de Trujillo is an educational institution that provides higher education at the master's and doctoral levels in different specialties. Graduates, especially from national universities, have the opportunity to specialize in one of the mentions offered by the Graduate School, one of them being the mention in Administration and Management of Information Technologies, belonging to the Engineering section, where the academic semester is made up of 17 weeks, in which these classes are generally taught on weekends, trying to provide the best facilities for students to be able to attend regularly and avoid their losses or their probable disqualification. Currently the classes are divided into different schedules, between Saturdays and Sundays, morning and afternoon; despite the convenience of the schedules; There are various reasons why students cannot attend the classes scheduled at these hours, whether they are personal and / or work reasons, taking into account that several of them do not reside in the city of Trujillo or its districts, for which reason they are It is very difficult to attend these classes, as well as there are a large number of students who work on Saturdays, so they are also affected academically or at work. If a student misses classes on a weekend, it is a loss of $25 \%$ of the course content, being affected in the moments of exams and / or pending work; in the same way, there are students who cannot attend on Saturday mornings, the same percentage of loss of classes would be estimated. Those affected are also some teachers, who reside in other cities and many times find it necessary to postpone the scheduled class due to various factors, having to extend the academic semester, varying the work schedule established for the following courses and not even it reaches the full content of the courses. All these drawbacks made it suggest the need to improve the teaching-learning process (Martí, 2008), two situations that must be covered by teacher-students until the problem is solved. According to Martínez and Sánchez (2011) with the use of an e-Learning system, there is a clear parallelism between the evolution of ICT and the development of online training models. According to UOCInnova (2011), the e-Learning system is being accepted and used by various higher-level educational institutions; where students and teachers will replace physical classrooms with virtual classrooms from any remote site with internet access and with flexible schedules in these types of systems. Students will be able to access classes at the times they deem appropriate and in this way they will not interfere with other activities that they have to carry out during the day. The set of tools of an LMS allows to perform five main functions: (i) the administration of the EA; (ii) the communication of the participants; (iii) content management; (iv) management of group work, and (v) evaluation (Fernández and Cesteros, 2009).

\section{Materials and Methods}

The population was the students enrolled in Postgraduate, with a mention in Administration and Direction of Information Technology in the semesters 2011-I and 2011-II. The sample was 40, non-probability sampling for convenience was used. The analytical method was used (Hurtado and Toro, 2005). The design was a pre-experimental design with pre-test and post-test (Hernández et al., 1997). The scheme is as follows:

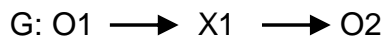

Where:

G: Postgraduate students with a minor in Information Technology Management and Administration in the 2011-I and 2011-II semesters.

01: The degree of student participation before the implementation of an E-Learning system in the 2011-I and 2011-II semesters.

O2: The degree of student participation after the implementation of an E-Learning system in the 2011-I and 2011-II semesters. 


\section{Journal of Sciences and Engineering}

Vol. 4, $\mathrm{N}^{\circ} 2,2020$

Copyright (C) 2020, CINCADER.

ISSN 2523-9503

DOI: https://doi.org/10.32829/sej.v4i2.183
Centre of Research and Training for

Regional Development

Online at www.journals.cincader.org

For the development of the E-Learning system the RUP methodology was used. According to Fowler and Scott (1997) the phases are: Conception Phase (Start), Elaboration Phase, Construction Phase, Transition Phase. The Methodology for the Creation of Virtual Learning Environments was considered (Mendoza and Galvis, 1999) that presents the phases: Analysis, Design, Development, Evaluation and Administration. The e-learning strategy consisted of internal relationships between the elements that make up the learning materials and prior knowledge. The teaching methods that were applied were: lecture, case study, solving exercises and problems, problem-based learning, cooperative learning.

For this, a questionnaire was used as research instruments according to García (2003).

The questions asked were:

Question 01: Can you fully access the sessions of the Graduate School courses?

Question 02: Are the schedules consistent with your personal and / or work schedule?

Question 03: Are you satisfied with the methodology used?

Question 04: Do you consider that the objectives set for the Postgraduate courses are met?

Question 05: Do you consider the study schedule at the Graduate School appropriate?

Question 06: Do you consider appropriate the times established for the hours of practical courses?

\section{Results}

The results obtained from the statistical treatment of the data before and after the implementation of the e-learning system based on the questions asked were the following:

Question 1: Full access to the sessions by students of the Graduate School of the Universidad Nacional de Trujillo with a major in Information Technology Management and Direction.

Table 1. Results of question 1

\begin{tabular}{|c|c|c|c|c|}
\hline & Before & After & Sample 1 (P1) & Sample 2 (P2) \\
\hline Face-to-face & 26 & 2 & $26 / 40=0,65$ & $2 / 40=0,05$ \\
\hline Distance learning & 14 & 38 & & \\
\hline
\end{tabular}

Where: P1: population proportion $($ before $)=0.65 ;$ P2: population proportion $($ after $)=0.05$

Ho (Null Hypothesis): the proportion of graduate school students DO NOT fully access the course sessions.

$\mathrm{Ha}$ (Alternative Hypothesis): the proportion of SI Graduate school students fully access the course sessions.

$\mathrm{P} 1=0.65$ and $\mathrm{P} 2=0.05$ were obtained, deducing that $\mathrm{P} 1>\mathrm{P} 2$. Therefore Ha was accepted.

Question 2: Concordance of the study schedules with the personal and / or work schedules of the students of the Graduate School of the Universidad Nacional de Trujillo with a major in Information Technology Management and Administration.

Table 2. Results of question 2

\begin{tabular}{|c|c|c|c|c|}
\hline & Before & After & Sample 1 (P1) & Sample 2 (P2) \\
\hline Face-to-face & 13 & 4 & $13 / 40=0,325$ & $4 / 40=0,1$ \\
\hline Distance learning & 27 & 36 & & \\
\hline
\end{tabular}




\section{Journal of Sciences and Engineering}

Vol. 4, $\mathrm{N}^{\circ}$ 2, 2020

Copyright (c) 2020, CINCADER.

ISSN 2523-9503

DOI: https://doi.org/10.32829/sej.v4i2.183

Where: P1: population proportion (before) $=0.325 ; \mathrm{P} 2$ : population proportion (after) $=0.1$

Ho (Null Hypothesis): the proportion of graduate school students DOES NOT match their academic schedules with their personal and / or work schedules.

$\mathrm{Ha}$ (Alternative Hypothesis): the proportion of students from the Graduate School YES agrees their academic schedules with their personal and / or work schedules.

$\mathrm{P} 1=0.325$ and $\mathrm{P} 2=0.1$ were obtained, deducing that P1 $\mathrm{P} 2$. Therefore it was accepted $\mathrm{Ha}$

Question 3: Compliance with the methodology used by the students of the Graduate School of the Universidad Nacional de Trujillo with a major in Information Technology Management and Direction

Table 3. Results of question 3

\begin{tabular}{|c|c|c|c|c|}
\hline & Before & After & Sample 1 (P1) & Sample 2 (P2) \\
\hline Face-to-face & 29 & 4 & $29 / 40=0,725$ & $4 / 40=0,1$ \\
\hline Distance learning & 11 & 36 & & \\
\hline
\end{tabular}

Where: P1: population proportion (before) $=0.725$; P2: population proportion (after) $=0.1$

Ho (Null Hypothesis): the proportion of graduate school students is NOT in agreement with the methodology used.

$\mathrm{Ha}$ (Alternative Hypothesis): the proportion of students from the Graduate School $\mathrm{SI}$ is in accordance with the methodology used.

$\mathrm{P} 1=0.725$ and $\mathrm{P} 2=0.1$ were obtained, deducing that P1>P2 Therefore, Ha was accepted

Question 4: Fulfillment of the objectives of the courses of the Postgraduate students of the Universidad Nacional de Trujillo with a major in Administration and Management of Information Technologies

Table 4. Results of question 4

\begin{tabular}{|c|c|c|c|c|}
\hline & Before & After & Sample 1 (P1) & Sample 2 (P2) \\
\hline Face-to-face & 22 & 4 & $22 / 40=0,55$ & $4 / 40=0,1$ \\
\hline Distance learning & 18 & 36 & & \\
\hline
\end{tabular}

Where: P1: population proportion (before) $=0.55 ; \mathrm{P} 2$ : population proportion (after) $=0.1$

Ho (Null Hypothesis): the proportion of graduate school students consider that the course objectives are NOT met.

$\mathrm{Ha}$ (Alternative Hypothesis): the proportion of Graduate school students consider that YES the course objectives are met.

$\mathrm{P} 1=0.55$ and $\mathrm{P} 2=0.1$ were obtained, deducting $\mathrm{P} 1>\mathrm{P} 2$, therefore Ha was accepted 


\section{Journal of Sciences and Engineering}

Vol. 4, $\mathrm{N}^{\circ}$ 2, 2020

Copyright (c) 2020, CINCADER.

ISSN 2523-9503

DOI: https://doi.org/10.32829/sej.v4i2.183

Question 5: Compliance with the study schedules established in the Graduate School of the Universidad Nacional de Trujillo with a mention in Administration and Management of Information Technology

Table 5. Results of question 5

\begin{tabular}{|c|c|c|c|c|}
\hline & Before & After & Sample 1 (P1) & Sample 2 (P2) \\
\hline Face-to-face & 19 & 3 & $19 / 40=0,475$ & $3 / 40=0,075$ \\
\hline Distance learning & 21 & 37 & & \\
\hline
\end{tabular}

Where:

P1: population proportion (before) $=0.475$

P2: population proportion (after) $=0.075$

Ho (Null Hypothesis): the proportion of Graduate school students is NOT in accordance with the schedules established by the Graduate school.

$\mathrm{Ha}$ (Alternative Hypothesis): the proportion of students from the Graduate school IS in accordance with the schedules established by the Graduate school.

$\mathrm{P} 1=0.475$ and $\mathrm{P} 2=0.075$ were obtained, deducing that $\mathrm{P} 1>\mathrm{P} 2$, therefore Ha was accepted

Question 6: Compliance with the times established for the hours of practice of the courses for students of the Universidad Nacional de Trujillo with a major in Administration and Management of Information Technologies.

Table 6. Results of question 6

\begin{tabular}{|c|c|c|c|c|}
\hline & Before & After & Sample 1 (P1) & Sample 2 (P2) \\
\hline Face-to-face & 27 & 1 & $27 / 40=0,676$ & $1 / 40=0,025$ \\
\hline Distance learning & 13 & 39 & & \\
\hline
\end{tabular}

Where: P1: population proportion (before) $=0.676$; P2: population proportion (after) $=0.025$

Ho (Null Hypothesis): the proportion of students from the Graduate school does NOT conform to the hours of practice established for the courses.

$\mathrm{Ha}$ (Alternative Hypothesis): the proportion of students from the Graduate School IS in accordance with the hours of practice established for the courses.

$\mathrm{P} 1=0.676$ and $\mathrm{P} 2=0.025$ were obtained, deducing that $\mathrm{P} 1>\mathrm{P} 2$, therefore $\mathrm{Ha}$.

\section{Conclusions}

The majority of students (95\%) manage to access all class sessions in a timely manner, considerably reducing their absence, avoiding the loss of classes. The system adapts quite flexibly to the schedules of the students $(90 \%)$, benefiting them both in their field of work and studies. $90 \%$ of students agree with the virtual teaching methodology applied by the e-Learning system, making better use of the resources it offers. 


\section{SE \\ Journal of Sciences and \\ Engineering}

Vol. 4, $\mathbf{N}^{\circ}$ 2, 2020

Copyright (c) 2020, CINCADER.

ISSN 2523-9503

DOI: https://doi.org/10.32829/sej.v4i2.183

$90 \%$ of students are satisfied with meeting the objectives set for the courses compared to only $45 \%$ of students following face-to-face teaching in the classroom. Of the total number of students, $92.5 \%$ consider the study schedule provided by the Graduate School of the Universidad Nacional de Trujillo with the e-Learning system to be appropriate. $97.5 \%$ of the students demonstrate their satisfaction with the practical hours of the courses, since they can be carried out at any time within an assigned period of the week.

\section{Acknowledgments}

Our sincere gratitude to the Graduate School of the Universidad Nacional de Trujillo for facilitating access and the corresponding information and to the Postgraduate students with a major in Information Technology Management and Direction for giving us their time in carrying out this document. Investigation.

\section{References}

Fernández A. and Cesteros P. 2009. Las plataformas e-learning para la enseñanza y el aprendizaje universitario en Internet. https://eprints.ucm.es/10682/1/capituloE_learning.pdf
Fowler
$\mathrm{M}$.
and
Scott
K. $\quad 1999$.
UML
gota
a gota. https://ingenieriasoftware2011.files.wordpress.com/2011/07/uml-gota-a-gota.pdf.

García T. El cuestionario como instrumento de investigación/evaluación. https://www.buenastareas.com/ensayos/Evaluacion-Aprendizaje/272948.html

Hernández R., Fernández C. y Baptista P. 1997. Metodología de la Investigación. McGraw - Hill.

Hurtado I. and Toro J. Paradigmas y métodos de investigación. 2005.https://epinvestsite.files.wordpress.com/2017/09/paradigmas-libro.pdf

Martí J. 2008. Aprendizaje mezclado (B-Learning) Modalidad de formación de profesionales. Revista Universidad EAFIT. Colombia.

Martínez E. and Sánchez S. 2011. El proceso enseñanza aprendizaje. https://educomunicacion.es/didactica/0014procesoaprendizaje.htm.

Mendoza P. and Galvis A. Ambientes Virtuales de Aprendizaje: Una Metodología para su creación. 1999. Informática Educativa UNIANDES - LIDIE, 12(2), 295-317.

UOCInnova, 2011. Evolución y retos de la Educación Virtual. http://openaccess.uoc.edu/webapps/o2/bitstream/10609/9781/1/TRIPA_e-learning_castellano.pdf 